\title{
REVIEW
}

\section{Primary effusion lymphoma in an elderly patient effectively treated by lenalidomide: case report and review of literature}

\author{
A Antar ${ }^{1,4}, \mathrm{H} \mathrm{El} \mathrm{Hajj}{ }^{1,4}, \mathrm{M} \mathrm{Jabbour}^{2}$, I Khalifeh ${ }^{2}, \mathrm{~F} \mathrm{EL-Merhi}{ }^{3}, \mathrm{R} \mathrm{Mahfouz}^{2}$ and A Bazarbachi ${ }^{1}$
}

Primary effusion lymphoma (PEL) is a rare aggressive subset of non-Hodgkin B-cell lymphoma. It is caused by Kaposi sarcomaassociated herpesvirus/human herpesvirus type 8 (KSHV/HHV8). It occurs mainly, but not exclusively, in HIV-positive patients. PEL predominantly develops in serous cavities and occasionally in extracavitary regions. PEL carries a very poor prognosis with a median survival time of $<6$ months. Indeed, currently used treatment modalities such as CHOP chemotherapy are far from achieving complete and sustainable remission. Therefore, there is no clear standard of care established in the treatment of PEL patients, stressing the need for novel-targeted approaches. Here, we have attempted a comprehensive assessment of the treatment of PEL, discussed avant-garde therapies and updated the state of preclinical research with promising clinical applications in the field. These include inhibitors of viral replication, modulators of cell signaling and inflammation, nuclear factor kappa B (NF- $\kappa \mathrm{B})$ and histone deacetylase inhibitors, and recently the combination of arsenic trioxide and interferon-alpha. Some of these targeted therapies have not yet reached clinical studies, although others were used in a few individual case reports with low numbers of patients. We also describe the first case of a 77-year-old, HIV-negative, HHV8-positive patient diagnosed with PEL limited to the pleural and peritoneal cavities. He received lenalidomide $25 \mathrm{mg} /$ day for 21 days every 28 days. Treatment was well tolerated with no side effects. He rapidly improved after 1 month of treatment and progressively achieved complete remission persistent after 18 months of therapy. We believe that this review will bridge an important gap between classical chemotherapy and modern approaches of targeted therapy. Finally, our findings warrant further evaluation of lenalidomide in future prospective clinical studies.

Blood Cancer Journal (2014) 4, e190; doi:10.1038/bcj.2014.6; published online 7 March 2014

\section{INTRODUCTION}

Primary effusion lymphoma (PEL) is a rare aggressive non-Hodgkin B-cell lymphoma that was first described in 1989 as body cavitybased lymphomas. ${ }^{1,2}$ It is caused by Kaposi sarcoma-associated herpesvirus/human herpesvirus type 8 (KSHV/HHV8) ${ }^{3-5}$ and accounts for $\sim 3 \%$ of AIDS-related lymphomas. ${ }^{6}$ It occurs mainly, but not exclusively, in HIV-positive patients, and less frequently in other groups such as elderly patients or organ transplantation recipients. ${ }^{7-9}$ The majority of PELs occur exclusively as lymphomatous effusions in serous cavities such as pleural, pericardial or abdominal cavities. ${ }^{10}$

PEL is generally resistant to chemotherapy and carries a dismal prognosis with a median survival of around 6 months. ${ }^{1-16}$ Given its rarity, there are only very few observational series of patients with PEL, and very few prospective trials testing chemotherapy, antiviral therapy or targeted therapy in that setting. Therefore, there is no clear standard of care established in the treatment of PEL patients.

Lenalidomide is an immunomodulatory drug that is commonly used to treat newly diagnosed and relapsed multiple myeloma ${ }^{17}$ as well as a variety of hematological malignancies such as chronic lymphocytic leukemia, mantle cell and diffuse large B-cell lymphomas and myelodysplasias. ${ }^{18-24}$ Furthermore, lenalidomide was successfully used to treat three patients with advanced refractory Kaposi sarcoma. ${ }^{25}$ It exerts its antitumor action through various mechanisms such as activation of the immune system, inhibition of angiogenesis and direct antineoplastic effects. ${ }^{26}$

\section{CASE PRESENTATION}

A 77-year-old man presented with a 2-month history of increasing abdominal girth. The patient had a history of coronary artery disease, congestive heart failure and brain surgery for intracerebral hemorrhage. No history of malignancy, HIV, hepatitis B or hepatitis $C$ infection was noted. Computed tomography (CT) scan of abdomen and pelvis showed a large cystic peritoneal mass sizing up to $30-35 \mathrm{~cm}$ in greatest dimension. He underwent a surgical resection of the cystic lesion that turned out to be a chronically inflamed fibromembranous adipose tissue. Two months later, he was admitted because of severe dyspnea. CT scan of the chest and PET-CT scan revealed bilateral pleural effusion, without evidence of abnormal metabolic uptake. Bilateral pig tails were inserted with successful drainage of the effusion. Cytopathology of pleural fluid revealed a clone of malignant lymphoid cells with high N/C ratio, multiple nucleoli and frequent mitosis (Figures 1a and b). By immunohistochemistry, the cells were positive for CD38 and EMA only, and negative for CD45, CD20, CD3, CD43, PAX-5, CD34, CD68, CD117, CD30, TdT, myeloperoxidase, $\mathrm{S}-100$ and CKAE1/3 (Figures $1 \mathrm{c}-\mathrm{f}$ and not shown). Flow cytometry on the pleural fluid revealed positivity for CD38 and EMA whereas CD138, CD16 and CD56 were negative. Overall, the clinical and pathological features were consistent with PEL. Moreover, a review of pathology of the previous abdominal cyst was consistent with the same diagnosis. Bone marrow biopsy was negative for malignancy. HHV8 serology was positive. HIV serology was negative. Repeated CT scan of the chest after 1 week

${ }^{1}$ Division of Hematology and Oncology, Department of Internal Medicine, American University of Beirut Medical Center, Beirut, Lebanon; ${ }^{2}$ Department of Pathology and Laboratory Medicine, American University of Beirut Medical Center, Beirut, Lebanon and ${ }^{3}$ Department of Radiology, American University of Beirut Medical Center, Beirut, Lebanon. Correspondence: Professor A Bazarbachi, Department of Internal Medicine, American University of Beirut, Beirut PO Box 113-6044, Lebanon.

E-mail: bazarbac@aub.edu.lb

${ }^{4}$ These authors contributed equally to this work.

Received 22 January 2014; accepted 24 January 2014 

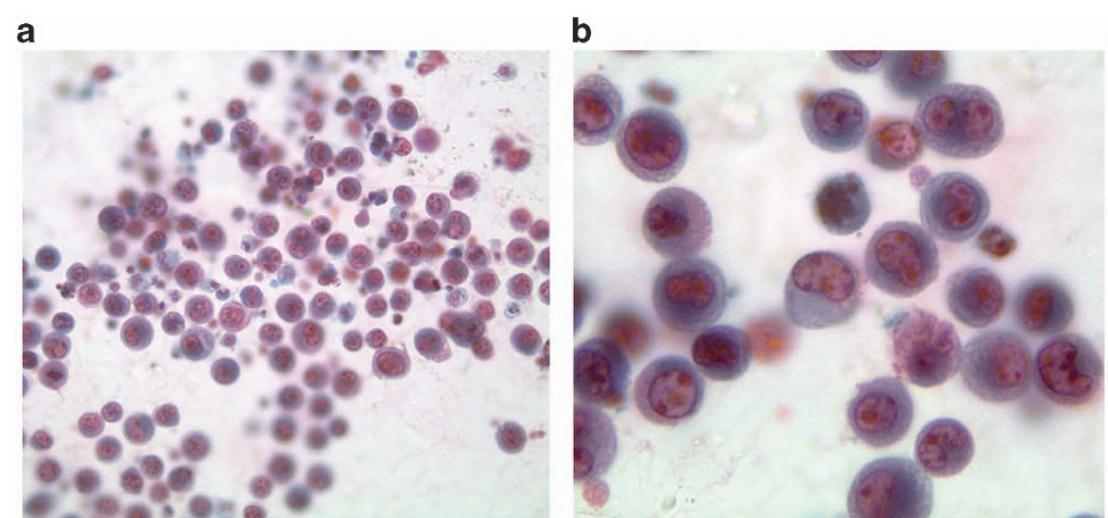

C
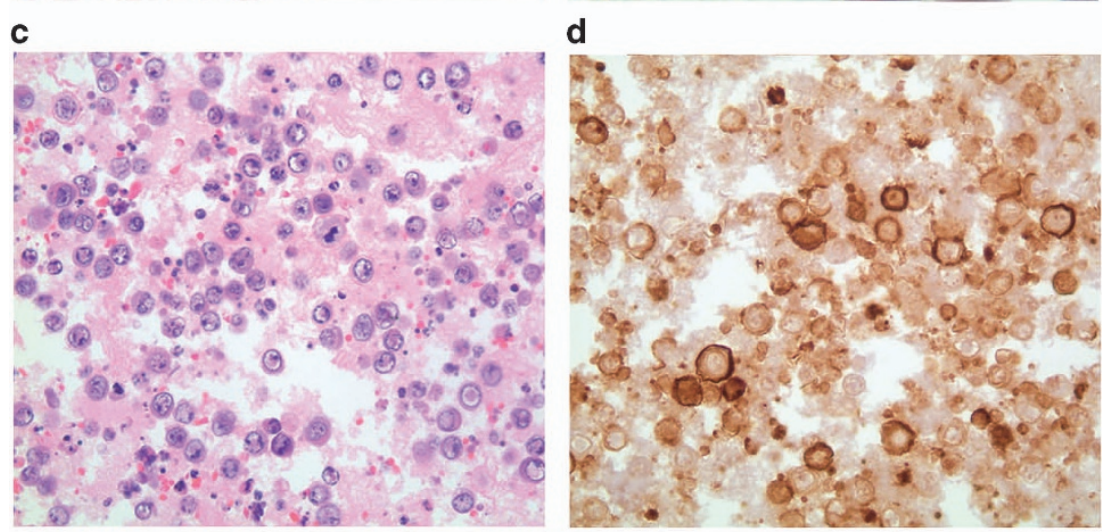

e

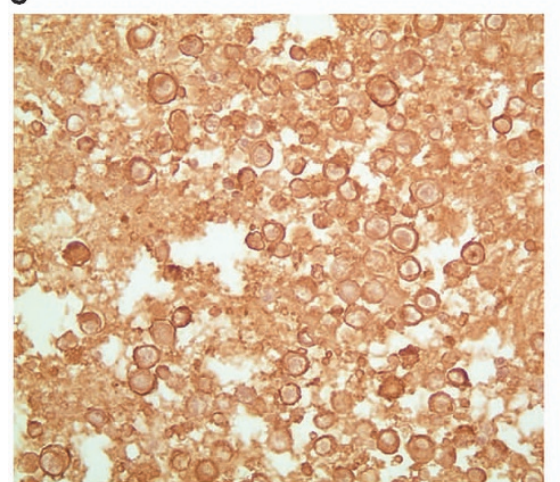

f

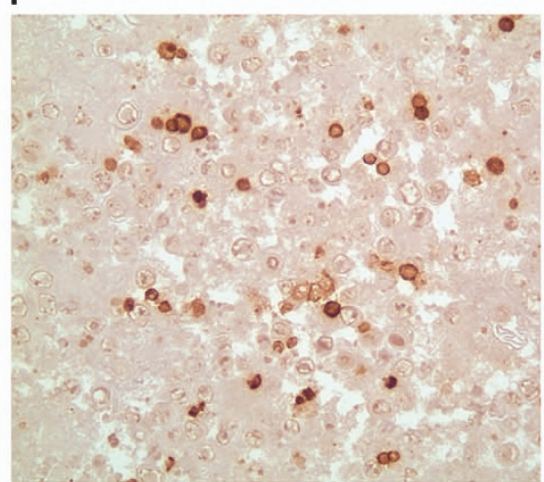

g

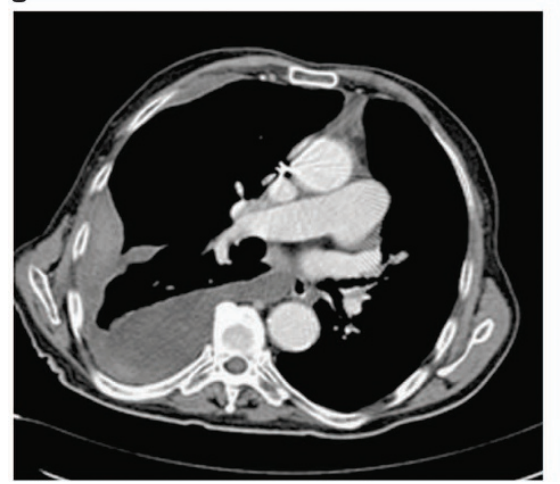

h

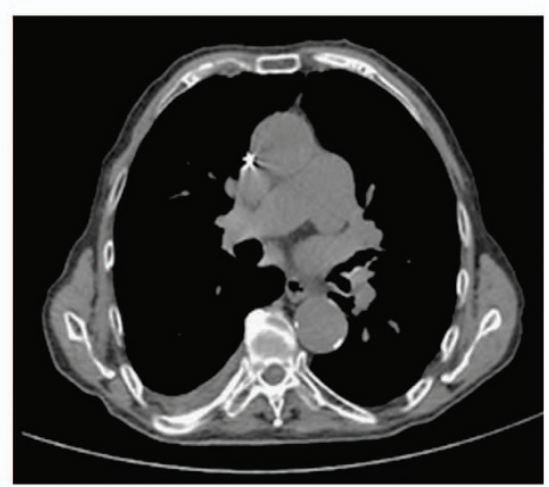

Figure 1. Diagnostic features and follow-up in a PEL patient. (a, b) Pleural fluid with hypercellular areas composed of discohesive, large, atypical cells characterized by a high nucleocytoplasmic ratio, occasional nuclear bilobation and eccentric nuclei with multiple peripheral nucleoli reminiscent of atypical plasma cells (magnification: $\mathbf{a} \times 400$ and $\mathbf{b} \times 1000)$. (c-f) Pleural fluid cell block (H\&E stain: c; immunohistochemistry $\mathbf{d}$-f; magnification $\times 400)$ showing the discohesive atypical cells $(\mathbf{c})$, expressing plasma cell marker CD38 (d) and EMA (e) but negative for CD45 (f). (g, h) Computed Tomography axial single slice showing pretreatment reaccumulation of the right pleural fluid after successful drainage $(\mathbf{g})$ and significant improvement of the right pleural fluid after 8 months of treatment by lenalidomide (h). 
of pig tail removal showed a significant reaccumulation of the effusion, notably on the right side (Figure 1g).

Because of the patient age and clinical condition, he was started on lenalidomide $25 \mathrm{mg}$ p.o. daily for 21 days every 28 days for each cycle. He had a significant improvement of his dyspnea after the first cycle. Monthly chest $X$ rays and $C T$ scan of chest after eight cycles of treatment showed a major decrease in the right pleural effusion with complete resolution of the left pleural effusion (Figure $1 \mathrm{~h}$ ). Treatment was relatively well tolerated and no side effects were noted. He has been on lenalidomide for 18 months so far, without any symptoms or evidence of disease progression.

\section{DIAGNOSIS OF PEL}

The diagnosis of PEL is based on the combination of clinical features, morphology, immunophenotype, virology and molecular findings. The cytological preparations (for example, smears, cytospin and cell block) of the malignant effusion constitute the main material for pathologic examination and diagnosis. The cytologic features are usually large cells with moderate to abundant basophilic cytoplasm, round to irregular nuclei and prominent nucleoli. The cells show a range in appearance from immunoblastic to plasmablastic to anaplastic. ${ }^{27}$ Immunophenotypically, and although of B-cell origin, PEL cells express leukocyte common antigen (CD45) and post-germinal center B cell/plasma cellassociated antigens (CD38, CD138) suggesting a late stage of B-cell differentiation, ${ }^{28,29}$ but classic B-cell markers (CD19, CD20, CD79a) and T-cell markers (CD3, CD4, CD8) are absent. ${ }^{29-31}$ In more detail and among 61 cases of PEL reported in the literature, 93\% were CD45 positive, $73 \%$ were CD30 positive, and finally, $T$ - and B-cell markers were expressed in 4.9 and $1.6 \%$, respectively. ${ }^{32}$ The HHV8 gene expression pattern in PEL cells is mostly latent with expression of LANA-1/2, kaposin and cellular homologs such as v-cyclin, v-FLIP, and to a lesser extent v-IL-6 (ref. 28). PEL cells are commonly co-infected by EBV ${ }^{10}$ that can be specifically detected by in situ hybridization for EBV RNA. However, EBV latent membrane protein 1 staining is negative until reactivation. ${ }^{33,34}$ Molecular analysis usually demonstrates the post-germinal center B-cell origin of PEL by revealing a clonal immunoglobulin gene rearrangements and somatic hypermutation. ${ }^{35}$

\section{TREATMENT OF PEL}

Chemotherapy

Boulanger et al. ${ }^{36}$ described the largest series of PEL patients $(n=28)$ with a median follow-up of 3.8 years. This multicenter retrospective clinical series showed a median survival of 6.2 months and a 1-year overall survival rate of $39.3 \%$. No standard treatment is currently available for PEL. The data from six large and most recent PEL published series are summarized in Table 1. The backbone therapy in all these series is CHOP-based chemotherapy (cyclophosphamide, doxorubicin, vincristine, and prednisone). Some patients received more intensive chemotherapy by adding methotrexate to $\mathrm{CHOP}$ or by increasing the dose intensity (ACVBP). ${ }^{12,13,37}$ Complete remission was achieved in $43 \%$ when CHOP-like chemotherapy was used in one study ${ }^{11}$ and $57 \%$ and $67 \%$, respectively, when more intensive regimen (CHOPlike + MTX or ACVBP) was used in other studies. ${ }^{13,37}$ Although the intensive chemotherapy seems to be more effective, most patients cannot tolerate it probably because of the low CD4 + cell count and/or poor performance status in HIV-positive patients and the old age in HIV-negative patients. Moreover, methotrexate tends to accumulate in the effusions, which delayed its clearance and increased toxicity. ${ }^{38,39}$ Although methotrexate accumulation in serous effusions might be beneficial to patients with PEL, it should be used with caution using intensive hydration, daily monitoring of methotrexate level and leucovorin rescue maintenance until complete methotrexate elimination. Otherwise, methotrexate can be associated with severe systemic toxicity. ${ }^{40}$

\section{Stem cell transplantation}

High-dose chemotherapy and autologous stem cell transplant (ASCT) have been described in two case reports. ${ }^{41,42}$ The first case was an HIV-negative patient with relapsed PEL who was successfully treated by $\mathrm{ASCT}^{41}$ and the second case was an HIVpositive PEL who had an early progression after $\mathrm{ASCT} .{ }^{42}$ On the basis of extrapolation from other studies in HIV-related lymphomas, ${ }^{43}$ ASCT can be considered in patients with relapsed PEL who respond to salvage chemotherapy. However, ASCT as a consolidation therapy in first-line complete remission patients is not supported by any evidence so far. In addition, one case of successful allogeneic stem cell transplantation has been reported in an HIV-positive PEL patient. ${ }^{44}$

\section{Antiviral therapy}

In the pre-HAART era and despite the use of the same chemotherapy regimens as today, the outcome of HIV-positive PEL patients was dismal. ${ }^{14,15}$ Indeed, the absence of HAART before PEL diagnosis was associated with poor outcome in a multivariate analysis. ${ }^{36}$ In addition, complete remissions have been reported after treatment of PEL patients by HAART alone. ${ }^{4-47}$ Hence, it is recommended to continue or initiate HAART as a part of

Table 1. Clinical series of primary effusion lymphoma patients

\begin{tabular}{|c|c|c|c|c|c|c|}
\hline & Boulanger et al. ${ }^{36}$ & Simonelli et al. ${ }^{11}$ & Boulanger et al. ${ }^{13}$ & Boulanger et al. ${ }^{12}$ & Valencia et al. ${ }^{14}$ & Nador et al. ${ }^{15}$ \\
\hline Number of patients & 28 & 11 & 7 & 12 & 7 & 15 \\
\hline Male & $96 \%$ & $90 \%$ & $100 \%$ & $100 \%$ & $86 \%$ & $100 \%$ \\
\hline HIV positive & $100 \%$ & $100 \%$ & $100 \%$ & $100 \%$ & $100 \%$ & $87 \%$ \\
\hline EBV co-infection & $72 \%$ & $\mathrm{n} / \mathrm{a}$ & $57 \%$ & $92 \%$ & - & $93 \%$ \\
\hline History of Kaposi sarcoma & $67 \%$ & $27 \%$ & $71 \%$ & $50 \%$ & $43 \%$ & $33 \%$ \\
\hline Extra-cavitary disease & $43 \%$ & $45 \%$ & $71 \%$ & $42 \%$ & $0 \%$ & $13 \%$ \\
\hline HAART & $78 \%$ & $72 \%$ & $71 \%$ & $50 \%$ & $14 \%$ & $0 \%$ \\
\hline CHOP-like chemotherapy & $36 \%$ & $72 \%$ & $0 \%$ & $50 \%$ & $85 \%$ & $n / a$ \\
\hline CR rate & $10 \%$ & $43 \%$ & $\mathrm{n} / \mathrm{a}$ & $17 \%$ & $\mathrm{n} / \mathrm{a}$ & $n / a$ \\
\hline CHOP-like + methotrexate & $35 \%$ & $0 \%$ & $100 \%$ & $17 \%$ & $0 \%$ & $\mathrm{n} / \mathrm{a}$ \\
\hline CR rate & $70 \%$ & $\mathrm{n} / \mathrm{a}$ & $57 \%$ & $50 \%$ & $\mathrm{n} / \mathrm{a}$ & $n / a$ \\
\hline ACVBP & $8 \%$ & $0 \%$ & $0 \%$ & $8 \%$ & $0 \%$ & $\mathrm{n} / \mathrm{a}$ \\
\hline CR rate & $50 \%$ & $\mathrm{n} / \mathrm{a}$ & $\mathrm{n} / \mathrm{a}$ & $0 \%$ & $\mathrm{n} / \mathrm{a}$ & $\mathrm{n} / \mathrm{a}$ \\
\hline Median overall survival & 6.2 months & 6 months & 9 months & 5 months & 2 months & 4 months \\
\hline
\end{tabular}

Abbreviations: ACVBP, doxorubicin, cyclophosphamide, vindesine, bleomycin, prednisone; CHOP, cyclophosphamide, doxorubicin, vincristine, and prednisone; CR, complete remission; EBV, Epstein-Barr virus; HAART, highly active antiretroviral therapy; n/a, not applicable. 
Table 2. Preclinical studies in primary effusion lymphoma targeting the proteasome and/or the NF-kB pathway

\begin{tabular}{|c|c|c|c|c|}
\hline Study & Agent & Activity & Model & Key findings \\
\hline El Hajj et al. ${ }^{69}$ & $\begin{array}{l}\text { Combination of arsenic } \\
\text { trioxide and IFN }-\alpha\end{array}$ & $\begin{array}{l}\text { NF- } \kappa B \text { inhibition; } \\
\text { antiviral activity }\end{array}$ & $\begin{array}{l}\text { In vitro: } \mathrm{PEL} \text { cell lines; } \\
\text { in vivo: xenograft } \\
\text { mouse model }\end{array}$ & $\begin{array}{l}\text { Dramatic inhibition of proliferation, } \\
\text { induction of apoptosis and } \\
\text { downregulation of the latent viral } \\
\text { transcripts LANA-1, v-FLIP and v-Cyc; } \\
\text { decrease in the peritoneal volume and } \\
\text { prolonged survival of PEL mice }\end{array}$ \\
\hline Bhatt et al. ${ }^{63}$ & Proteasome/HDAC inhibitor & $\begin{array}{l}\text { Proteasome and } \\
\text { NF-kB inhibition; } \\
\text { histone } \\
\text { deacetylase } \\
\text { inhibition }\end{array}$ & $\begin{array}{l}\text { In vivo: xenograft } \\
\text { mouse model }\end{array}$ & $\begin{array}{l}\text { Extensive apoptosis and significant } \\
\text { survival advantage in PEL-bearing mice }\end{array}$ \\
\hline Goto et al. ${ }^{54}$ & $\begin{array}{l}\text { Berberine (isoquinoline } \\
\text { alkaloid) }\end{array}$ & NF- $\kappa B$ inhibition & $\begin{array}{l}\text { In vitro: } \mathrm{PEL} \text { cell lines; } \\
\text { in vivo: xenograft } \\
\text { mouse model }\end{array}$ & $\begin{array}{l}\text { Cell death by blocking the NF- } \kappa B \text { pathway } \\
\text { in PEL cells; antiretroviral activity }\end{array}$ \\
\hline Matsuno et al. ${ }^{37}$ & $\begin{array}{l}\text { Diethyldithio-carbamate } \\
\text { (DDTC) }\end{array}$ & NF- $\kappa B$ inhibition & $\begin{array}{l}\text { In vivo: xenograft } \\
\text { mouse model }\end{array}$ & Amelioration of PEL symptoms \\
\hline Higashi et al. ${ }^{56}$ & $\begin{array}{l}\text { Heat-shock protein } 90 \\
\text { inhibitors }\end{array}$ & NF-кB inhibition & In vitro: PEL cell lines & Induction of apoptosis in PEL cell lines \\
\hline Saji et al. ${ }^{62}$ & $\begin{array}{l}\text { MG132, lactacystin, } \\
\text { proteasome inh } 1\end{array}$ & $\begin{array}{l}\text { Proteasome and } \\
\text { NF- } \mathrm{KB} \text { inhibition }\end{array}$ & In vitro: PEL cell lines & $\begin{array}{l}\text { Inhibition of proliferation and induction of } \\
\text { apoptosis in PEL cells }\end{array}$ \\
\hline Sarosiek et al. ${ }^{16}$ & Bortezomib & $\begin{array}{l}\text { Proteasome and } \\
\text { NF- } \mathrm{B} \text { inhibition }\end{array}$ & $\begin{array}{l}\text { In vivo: xenograft } \\
\text { mouse model }\end{array}$ & $\begin{array}{l}\text { PEL remission and increase of overall } \\
\text { survival in PEL-treated mice }\end{array}$ \\
\hline Hussain et al. ${ }^{53}$ & Proteasome inhibitor: MG-132 & $\begin{array}{l}\text { Proteasome and } \\
\text { NF- } \mathrm{B} \text { B inhibition }\end{array}$ & In vitro: PEL cell lines & $\begin{array}{l}\text { Apoptosis of PEL cells via downregulation } \\
\text { of SKP2 leading to accumulation of } \\
\text { p27Kip1 }\end{array}$ \\
\hline Takahashi et al..$^{55}$ & $\begin{array}{l}\text { Biscoclaurine alkaloid } \\
\text { cepharanthine (CEP) }\end{array}$ & NF- $\kappa B$ inhibition & $\begin{array}{l}\text { In vitro: } \mathrm{PEL} \text { cell lines; } \\
\text { In vivo: xenograft } \\
\text { mouse model }\end{array}$ & $\begin{array}{l}\text { No significant systemic toxicity in this } \\
\text { model; dose-dependent inhibition of } \\
\text { proliferation and apoptosis of PEL cell lines }\end{array}$ \\
\hline Abou-Merhi et al. ${ }^{61}$ & $\begin{array}{l}\text { Bortezomib; combination of } \\
\text { arsenic and IFN- } \alpha\end{array}$ & $\begin{array}{l}\text { Proteasome and } \\
\text { NF- } \kappa B \text { inhibition }\end{array}$ & In vitro: PEL cell lines & $\begin{array}{l}\text { Dramatic inhibition of cell proliferation } \\
\text { and induction of apoptosis }\end{array}$ \\
\hline Matta et al. ${ }^{52}$ & Bortezomib & $\begin{array}{l}\text { Proteasome and } \\
\text { NF- } \kappa B \text { inhibition }\end{array}$ & In vitro: PEL cell lines & $\begin{array}{l}\text { More cytotoxicity against PEL cells than } \\
\text { against cell lines derived from multiple } \\
\text { myeloma }\end{array}$ \\
\hline An et al..$^{60}$ & $\begin{array}{l}\text { Bortezomib } \pm \text { chemotherapy } \\
\text { (doxorubicin and taxol) }\end{array}$ & $\begin{array}{l}\text { Proteasome and } \\
\text { NF- } \kappa B \text { inhibition }\end{array}$ & In vitro: $\mathrm{PEL}$ cell lines & $\begin{array}{l}\text { TRAIL-induced death, inhibition of cell } \\
\text { growth and induction of apoptosis in PEL } \\
\text { cells; synergy with chemotherapy }\end{array}$ \\
\hline
\end{tabular}

Abbreviations: HDAC, histone deacetylase; IFN- $\alpha$, interferon-alpha; NF-KB, nuclear factor kappa B; PEL, primary effusion lymphoma; TRAIL, tumor necrosis factor-related apoptosis inducing ligand.

supportive therapy in all HIV-positive PEL patients when treatment is started.

Antitumor activity of antiviral therapy against HHV8-associated PEL, whether related or not to HIV, has been reported in two studies that described prolonged complete remission after the intracavitary administration of cidofovir. ${ }^{48,49}$ Finally, one PEL patient showed a complete response when treated with azidothymidine (AZT) and interferon-alpha (IFN- $\alpha) .^{50}$ Cells from this patient as well as PEL cell lines showed that the pro-apoptotic effect of this combination is mediated by a concomitant activation of tumor necrosis factor-related apoptosis-inducing ligand and nuclear factor kappa B (NF- $\kappa$ B) inhibition. ${ }^{50}$ This result was consistent with the prolonged survival of PEL mice treated with AZT and IFN- $\alpha .{ }^{51}$

\section{Targeted therapy}

PEL tumor cells that are latently infected by KSHV/HHV8 display constitutive activity of many signaling pathways for growth and survival, including the NF- $\kappa B$, JAK/STAT (signal transducer and activator of transcription) and phosphoinositide3-kinase (PI3K)/AKT pathways. ${ }^{52-54}$ Several published preclinical studies on targeted therapy are shown in Tables 2 and 3. Since NF- $\kappa B$ activation seems to be a key player in PEL oncogenesis, the antitumor effect of proteasome inhibitors such as bortezomib was investigated in few preclinical trials and very few case reports. ${ }^{16,52,53,55-62}$ These drugs induce apoptosis of PEL cell lines in vitro and preclinical responses in vivo in xenograft PEL mouse models. In addition, a combination of proteasome inhibitor and chemotherapy ${ }^{60}$ or histone deacetylase inhibitor ${ }^{63}$ revealed a synergistic preclinical activity. Similarly, promising preclinical results were reported with multiple NF- $\mathrm{BB}$ inhibitors such as Berberine, diethyldithiocarbamate, cepharanthine and heat-shock protein 90 (refs. 37,54-56). Unfortunately, despite this promising preclinical efficacy of bortezomib, treatment of three chemotherapy refractory PEL patients with this drug alone or in combination with chemotherapy showed no improvement. ${ }^{64}$

Targeting the PI3-kinase pathway ${ }^{57,65}$ or the JAK/STAT pathway using a JAK2 inhibitor (tyrphostin AG490), or a dominant-negative STAT3-expressing vector, induced apoptosis of PEL cell lines. ${ }^{66}$ However, disappointing results with rapid resistance was reported with rapamycin (Sirolimus, St Louis, MO, USA), an inhibitor of mammalian target of rapamycin (mTOR) signaling. ${ }^{58,67}$ In addition, the anti-CD30/drug conjugate brentuximab vedotin (Adcetris, Bothell, WA, USA) showed promising preclinical anti-PEL effects. ${ }^{68}$ Finally, in HHV8-positive PEL cell lines, we demonstrated that the combination of arsenic trioxide and IFN inhibits growth and NF- $\kappa B$ activation and induces caspase-dependent apoptosis. ${ }^{61}$ Recently, we showed that in a preclinical NOD/SCID mouse model, this combination downregulates the latent viral transcripts LANA-1, v-FLIP and v-Cyc in PEL cells derived from malignant ascites, decreases the peritoneal volume and synergistically increases survival of PEL mice. ${ }^{69}$ 
Table 3. Preclinical studies in primary effusion lymphoma other than proteasome inhibition

\begin{tabular}{|c|c|c|c|c|}
\hline Study & Agent & Activity & Model & Key findings \\
\hline \multicolumn{5}{|c|}{ Targeting PI3-kinase pathway } \\
\hline Hussain et al. ${ }^{53}$ & Bay11-7085 \pm LY294002 & NF-KB $\pm \mathrm{PI} 3-\mathrm{K}$ inhibition & In vitro: PEL cell lines & Synergistic apoptotic responses in PEL cells \\
\hline Uddin et al..$^{65}$ & LY294002 & PI3-kinase inhibition & In vitro: PEL cell lines & $\begin{array}{l}\text { Apoptosis in all PEL cell lines studied except } \\
\text { BCP1 }\end{array}$ \\
\hline \multicolumn{5}{|c|}{ Targeting mTOR pathway } \\
\hline Gasperini et al. ${ }^{67}$ & Rapamycin (sirolimus) & mTOR inhibition & $\begin{array}{l}\text { In vitro: } \mathrm{PEL} \text { cell lines; } \\
\text { in vivo: xenograft } \\
\text { mouse model }\end{array}$ & $\begin{array}{l}\text { No eradication of PEL; after an initial } \\
\text { response, development of resistance in PEL } \\
\text { cells treated with rapamycin }\end{array}$ \\
\hline Sin et $a l^{58}$ & Rapamycin (sirolimus) & mTOR inhibition & $\begin{array}{l}\text { In vitro: } \mathrm{PEL} \text { cell lines; } \\
\text { in vivo: xenograft } \\
\text { mouse model }\end{array}$ & $\begin{array}{l}\text { Inhibition of PEL growth in culture; delay of } \\
\text { PEL progression in vivo }\end{array}$ \\
\hline \multicolumn{5}{|c|}{ Targeting STAT3 pathway } \\
\hline Aoki et al. ${ }^{66}$ & $\begin{array}{l}\text { Dominant-negative } \\
\text { STAT3 vector; tyrphostin } \\
\text { AG490 }\end{array}$ & $\begin{array}{l}\text { STAT3 inhibition } \\
\text { Jak2 inhibition }\end{array}$ & In vitro: PEL cell lines & $\begin{array}{l}\text { Induction of apoptosis and decrease of } \\
\text { survivin expression in PEL after inhibition of } \\
\text { STAT3 signaling }\end{array}$ \\
\hline \multicolumn{5}{|l|}{ Antiviral $\pm I F N-\alpha$} \\
\hline Fujimuro et al. ${ }^{70}$ & $\begin{array}{l}\text { Gancyclovir (purine } \\
\text { nucleoside analogs) }\end{array}$ & Antiviral activity & In vitro: PEL cell lines & $\begin{array}{l}\text { Cytotoxic activity toward KSHV-infected PEL } \\
\text { cells treated with gancyclovir but not with } \\
\text { acyclovir }\end{array}$ \\
\hline Wu et al. ${ }^{51}$ & AZT and IFN- $\alpha$ & Antiviral activity & $\begin{array}{l}\text { In vivo: xenograft } \\
\text { mouse model }\end{array}$ & Increased survival of PEL mice \\
\hline Lee et $a .^{59}$ & AZT and IFN- $\alpha$ & Antiviral activity & In vitro: $\mathrm{PEL}$ cell lines & $\begin{array}{l}\text { Minimal sensitivity to AZT alone but synergy } \\
\text { with IFN- } \alpha\end{array}$ \\
\hline \multicolumn{5}{|l|}{ Miscellaneous } \\
\hline Goto et al. ${ }^{71}$ & Zoledronic acid & $\begin{array}{l}\text { Induction of } \mathrm{Vg} 9 \mathrm{Vd} 2 \\
\text { T cells }\end{array}$ & $\begin{array}{l}\text { In vitro: } \mathrm{PEL} \text { cell lines; } \\
\text { in vivo: xenograft } \\
\text { mouse model }\end{array}$ & $\begin{array}{l}\text { Inhibition of growth of PEL cells and } \\
\text { improved survival of PEL mice }\end{array}$ \\
\hline Paul et al. ${ }^{72}$ & Nimesulide & COX-2 inhibitor & In vitro: $\mathrm{PEL}$ cell lines & Proliferation arrest \\
\hline Bhatt et al. ${ }^{68}$ & Brentuximab vedotin & $\begin{array}{l}\text { Anti-CD30 monoclonal } \\
\text { and drug conjugate }\end{array}$ & $\begin{array}{l}\text { In vitro: } \text { PEL cell lines; } \\
\text { in vivo: xenograft } \\
\text { mouse model }\end{array}$ & $\begin{array}{l}\text { Proliferation arrest in PEL cell lines; } \\
\text { prolonged survival in PEL mice }\end{array}$ \\
\hline Lan et al. ${ }^{73}$ & $\begin{array}{l}\text { Gamma-secretase } \\
\text { inhibitor (GSI) }\end{array}$ & $\begin{array}{l}\text { Intracellular activated } \\
\text { Notch1 (ICN) blockage }\end{array}$ & $\begin{array}{l}\text { In vivo: direct } \\
\text { xenograft model }\end{array}$ & $\begin{array}{l}\text { Delay of the onset of tumorigenesis of } \\
\text { treated PEL mice }\end{array}$ \\
\hline
\end{tabular}

Abbreviations: AZT, azidothymidine; HDAC, histone deacetylase; IFN- $\alpha$, interferon-alpha; KSVH, Kaposi sarcoma-associated herpesvirus; mTOR, mammalian target of rapamycin; NF-KB, nuclear factor kappa B; PEL, primary effusion lymphoma; PI3-K, phosphoinositide-3-kinase; STAT3, signal transducer and activator of transcription 3 .

\section{CONCLUSION}

PEL still carries a dismal prognosis and the currently used treatment modalities are yet far from achieving complete and sustainable remission. On the basis of recent preclinical data and translational studies, several new-targeted therapies are being explored. Treatment with the second generation immunomodulatory drug lenalidomide has never been reported in PEL patients. The dramatic and prolonged efficacy of lenalidomide in the case of an elderly patient with PEL warrants testing this novel agent in prospective studies.

\section{CONFLICT OF INTEREST}

The authors declare no conflict of interest.

\section{REFERENCES}

1 Knowles DM, Inghirami G, Ubriaco A, Dalla-Favera R. Molecular genetic analysis of three AIDS-associated neoplasms of uncertain lineage demonstrates their B-cell derivation and the possible pathogenetic role of the Epstein-Barr virus. Blood 1989; 73: 792-799.

2 Carbone A, Gloghini A. KSHV/HHV8-associated lymphomas. Br J Haematol 2008; 140: 13-24.

3 Cesarman E, Chang Y, Moore PS, Said JW, Knowles DM. Kaposi's sarcomaassociated herpesvirus-like DNA sequences in AIDS-related body-cavity-based lymphomas. N Engl J Med 1995; 332: 1186-1191.
4 Otsuki T, Kumar S, Ensoli B, Kingma DW, Yano T, Stetler-Stevenson $M$ et al. Detection of HHV-8/KSHV DNA sequences in AIDS-associated extranodal lymphoid malignancies. Leukemia 1996; 10: 1358-1362.

5 DePond W, Said JW, Tasaka T, de Vos S, Kahn D, Cesarman E et al. Kaposi's sarcoma-associated herpesvirus and human herpesvirus 8 (KSHV/HHV8)associated lymphoma of the bowel: report of two cases in HIV-positive men with secondary effusion lymphomas. Am J Surg Pathol 1997; 21: 719-724.

6 Carbone A, Gloghini A, Vaccher E, Zagonel V, Pastore C, Dalla Palma P et al. Kaposi's sarcoma-associated herpesvirus DNA sequences in AIDS-related and AIDS-unrelated lymphomatous effusions. Br J Haematol 1996; 94: 533-543.

7 Cesarman E, Nador RG, Aozasa K, Delsol G, Said JW, Knowles DM. Kaposi's sarcoma-associated herpesvirus in non-AIDS related lymphomas occurring in the body cavities. Am J Pathol 1996; 149: 53-57.

8 Gaidano G, Pastore C, Gloghini A, Cusini M, Nomdedeu J, Volpe G et al. Distribution of human hepersvirus-8 sequences throughout the spectrum of AIDS-related neoplasia. AIDS 1996; 10: 941-949.

9 Kapelushnik J, Ariad S, Benharroch D, Landau D, Moser A, Delsol G et al. Post renal transplantation human herpes virus 8-associated lymphoproliferative disorder and Kaposi's sarcoma. Br J Haematol 2001; 113: 425-428.

10 Fan W, Bubman D, Chadburn A, Harrington Jr WJ, Cesarman E, Knowles DM. Distinct subsets of primary effusion lymphoma can be identified based on their cellular gene expression profile and viral association. J Virol 2005; 79: 1244-1251.

11 Simonelli C, Spina M, Cinelli R, Talamini R, Tedeschi R, Gloghini A et al. Clinical features and outcome of primary effusion lymphoma in HIV-infected patients: a single-institution study. J Clin Oncol 2003; 21: 3948-3954.

12 Boulanger E, Agbalika F, Maarek O, Daniel MT, Grollet L, Sigaux F et al. A clinical, molecular and cytogenetic study of 12 cases of human herpesvirus 8 associated primary effusion lymphoma in HIV-infected patients. Hematol J 2001; 2: 172-179. 
13 Boulanger E, Daniel MT, Agbalika F, Oksenhendler E. Combined chemotherapy including high-dose methotrexate in $\mathrm{KSHV} / \mathrm{HHV} 8$-associated primary effusion lymphoma. Am J Hematol 2003; 73: 143-148.

14 Valencia M, Martinez P, Moreno V, Laguna F, Lahoz JG. AIDS-related body cavity-based lymphomas, herpesvirus-8 and HIV infection: a study of seven cases. AIDS 1999; 13: 2603-2605.

15 Nador RG, Cesarman E, Chadburn A, Dawson DB, Ansari MQ, Sald J et al. Primary effusion lymphoma: A distinct clinicopathologic entity associated with the Kaposi's sarcoma-associated herpes virus. Blood 1996; 88: 645-656.

16 Sarosiek KA, Cavallin LE, Bhatt S, Toomey NL, Natkunam Y, Blasini W et al. Efficacy of bortezomib in a direct xenograft model of primary effusion lymphoma. PNAS 2010; 107: 13069-13074.

17 Dimopoulos MA, Kastritis E, Rajkumar SV. Treatment of plasma cell dyscrasias with lenalidomide. Leukemia 2008; 22: 1343-1353.

18 Hernandez-llizaliturri FJ, Batoo SA. The emerging role of lenalidomide in the management of lymphoid malignancies. Ther Adv Hematol 2011; 2: 45-53.

19 Goy A, Sinha R, Williams ME, Kalayoglu Besisik S, Drach J, Ramchandren R et al. Single-agent lenalidomide in patients with mantle-cell lymphoma who relapsed or progressed after or were refractory to bortezomib: phase II MCL-001 (EMERGE) study. J Clin Oncol 2013; 31: 3688-3695.

20 Desai M, Newberry KJ, Romaguera J, Zhang L, Ou Z, Wang M. Immunomodulation therapy with lenalidomide in follicular, transformed and diffuse large B cell lymphoma: current data on safety and efficacy. J Hematol Oncol 2013; 2: 6-55.

21 Vose JM, Habermann TM, Czuczman MS, Zinzani PL, Reeder CB, Tuscano JM et al. Single-agent lenalidomide is active in patients with relapsed or refractory aggressive non-Hodgkin lymphoma who received prior stem cell transplantation. Br J Haematol 2013; 1625: 639-647.

22 Morschhauser F, Fitoussi O, Haioun C, Thieblemont C, Quach H, Delarue R et al. A phase 2, multicentre, single-arm, open-label study to evaluate the safety and efficacy of single-agent lenalidomide (Revlimid) in subjects with relapsed or refractory peripheral T-cell non-Hodgkin lymphoma: the EXPECT trial. Eur J Cancer 2013; 49: 2869-2876.

23 Wiernik PH. Lenalidomide in lymphomas and chronic lymphocytic leukemia. Expert Opin Pharmacother 2013; 14: 475-488.

24 Brown JR, Abramson J, Hochberg E, Mikler E, Dalton V, Werner L et al. A phase I study of lenalidomide in combination with fludarabine and rituximab in previously untreated CLL/SLL. Leukemia 2010; 24: 1972-1975.

25 Fux CA, Baumann S, Furrer H, Mueller NJ. Lenalidomide in treating AIDS-related Kaposi's sarcoma. AIDS 2011; 25: 878-880.

26 Heise C, Carter T, Schafer P, Chopra R. Pleiotropic mechanisms of action of lenalidomide efficacy in del(5q) myelodysplastic syndromes. Expert Rev Anticancer Ther 2010; 10: 1663-1672.

27 Pan ZG, Zhang QY, Lu ZB, Quinto T, Rozenvald IB, Liu LT et al. Extracavitary KSHV-associated large B-cell lymphoma: a distinct entity or a subtype of primary effusion lymphoma? Study of 9 cases and review of an additional 43 cases. Am J Surg Pathol 2012; 36: 1129-1140.

28 Schulz, Thomas F. The pleiotropic effects of Kaposi's sarcoma herpesvirus. J Patho 2006; 208: 187-198.

29 Carbone A, Gloghini A, Larocca LM, Capello D, Pierconti F, Cansonieri V et al. Expression profile of MUM1/IRF4, BCL-6, and CD138/syndecan-1 defines nove histogenetic subsets of human immunodeficiency virus-related lymphomas. Blood 2001; 97: 744-751.

30 Ohshima K, Suzumiya J, Kanda M, Haraoka S, Kawasaki C, Shimazaki K et al. Genotypic and phenotypic alterations in Epstein-Barr virus-associated lymphoma. Histopathology 1999; 35: 539-550.

31 Chen Y-B, Rahemtullah A, Hochberg E. Primary effusion lymphoma. Oncologist 2007; 12: 569-576.

32 Brimo F, Michel RP, Khetani K, Auger M. Primary effusion lymphoma: a series of 4 cases and review of the literature with emphasis on cytomorphologic and immunocytochemical differential diagnosis. Cancer 2007; 111: 224-233.

33 Spadavecchia S, Gonzalez-Lopez O, Carroll KD, Palmeri D, Lukac DM. Convergence of Kaposi's sarcoma-associated herpesvirus reactivation with Epstein-Barr virus latency and cellular growth mediated by the notch signaling pathway in coinfected cells. J Virol 2010; 84: 10488-10500.

34 Banks PM, Warnke RA. Primary effusion lymphoma. In: Jaffe ES, Harris NL, Stein H, Vardiman JW (eds) World Health Organization Classification of Tumors: Pathology and Genetics of Tumors of Haematopoietic and Lymphoid Tissues. IARC Press: Lyon 2001, pp 179-180.

35 Matolcsy A, Nador RG, Cesarman E, Knowles DM. Immunoglobulin VH gene mutational analysis suggests that primary effusion lymphomas derive from different stages of B cell maturation. Am J Pathol 1998; 153: 1609-1614.

36 Boulanger E, Gérard L, Gabarre J, Molina JM, Rapp C, Abino JF et al. Prognostic factors and outcome of human herpesvirus 8-associated primary effusion lymphoma in patients with AIDS. J Clin Oncol 2005; 23: 4372-4380.
37 Matsuno T, Kariyar R, Syano S, Morino-Koga S, Taura M, Suico MA et al. Diethyldithiocarbamate induces apoptosis in HHV-8-infected primary effusion lymphoma cells via inhibition of the NF-KB pathway. Int J Oncol 2012; 40: 1071-1078.

38 Wan SH, Huffman DH, Azarnoff DL, Stephens R, Hooqstraten B. Effect of route of administration and effusions on methotrexate pharmacokinetics. Cancer Res 1974; 34: 3487-3491.

39 Evans WE, Pratt CB. Effect of pleural effusion on high-dose methotrexate kinetics. Clin Pharmacol Ther 1978; 23: 68-72.

40 Vezmar S, Schüsseler P, Becker A, Bode U, Jaehde U. Methotrexate-associated alterations of the folate and methyl-transfer pathway in the CSF of ALL patients with and without symptoms of neurotoxicity. Pediatr Blood Cancer 2009; 52: 26-32.

41 Won JH, Han SH, Bae SB, Kim CK, Lee NS, Lee KT et al. Successful eradication of relapsed primary effusion lymphoma with high-dose chemotherapy and autologous stem cell transplantation in a patient seronegative for human immunodeficiency virus. Int J Hematol 2006; 83: 328-330.

42 Waddington TW, Aboulafia DM. Failure to eradicate AIDS-associated primary effusion lymphoma with high-dose chemotherapy and autologous stem cell reinfusion: case report and literature review. AIDS Patient Care STDS 2004; 18: 67-73.

43 Re A, Cattaneo C, Michieli M, Casari S, Spina M, Rupolo M et al. High-dose therapy and autologous peripheral- blood stem-cell transplantation as salvage treatment for HIV associated lymphoma in patients receiving highly active antiretroviral therapy. J Clin Oncol 2003; 21: 4423-4427.

44 Bryant A, Milliken S. Successful reduced-intensity conditioning allogeneic HSCT for HIV-related primary effusion lymphoma. Biol Blood Marrow Transplant 2008; 14: 601-602.

45 Oksenhendler E, Clauvel JP, Jouveshomme S, Davi F, Mansour G. Complete remission of a primary effusion lymphoma with antiretroviral therapy. Am J Hematol 1998; 57: 266.

46 Hocqueloux L, Agbalika F, Oksenhendler E, Molina JM. Long-term remission of an AIDS-related primary effusion lymphoma with antiviral therapy. AIDS 2001; 15 280-282.

47 Ripamonti D, Marini B, Rambaldi A, Suter F. Treatment of primary effusion lymphoma with highly active antiviral therapy in the setting of HIV infection. AIDS 2008; 22: 1236-1237.

48 Halfdanarson TR, Markovic SN, Kalokhe U, Luppi M. A non-chemotherapy treatment of a primary effusion lymphoma: Durable remission after intracavitary cidofovir in HIV negative PEL refractory to chemotherapy. Ann Oncol 2006; 17: 1849-1850.

49 Luppi M, Trovato R, Barozzi P, Vallisa D, Rossi G, Re A et al. Treatment of herpesvirus associated primary effusion lymphoma with intracavity cidofovir. Leukemia 2005; 19: 473-476.

50 Ghosh SK, Wood C, Boise LH, Mian AM, Deyev W, Feuer G et al. Potentiation of TRAIL induced apoptosis in primary effusion lymphoma through azidothymidinemediated inhibition of NF-kappa B. Blood 2003; 101: 2321-2327.

51 Wu Wi, Rochford R, Toomey L, Harrington Jr W, Feuer G. Inhibition of HHV-8/KSHV infected primary effusion lymphomas in NOD/SCID mice by azidothymidine and interferon- $\alpha$. Leuk Res 2005; 29: 545-555.

52 Matta H, Chaudhary PM. The proteasome inhibitor bortezomib (PS-341) inhibits growth and induces apoptosis in primary effusion lymphoma cells. Cancer Biol Ther 2005; 4: 77-82.

53 Hussain Ar, Ahmed M, Ahmed So, AL-Thari S, Khan AS, Razack S et al. Proteasome inhibitor MG-132 mediated expression of p27Kip1 via S-phase kinase protein 2 degradation induces cell cycle coupled apoptosis in primary effusion lymphoma cells. Leuk Lymphoma 2009; 50: 1204-1213.

54 Goto H, Kariya R, Shimamoto M, Kudo E, Taura M, Katano H et al. Antitumor effect of berberine against primary effusion lymphoma via inhibition of NF- $\kappa B$ pathway. Cancer Sci 2012; 103: 775-781.

55 Takahashi-Makise N, Suzu S, Hiyoshi M, Ohsugi T, Katano H, Umezawa K et al. Biscoclaurine alkaloid cepharanthine inhibits the growth of primary effusion lymphoma in vitro and in vivo and induces apoptosis via suppression of the NF-кB pathway. Int J Cancer 2009; 125: 1464-1472.

56 Higashi C, Saji C, Yamada K, Kagawa H, Ohqa R, Taira T et al. The effects of heat shock protein 90 inhibitors on apoptosis and viral replication in primary effusion lymphoma cells. Biol Pharm Bull 2012; 35: 725-730.

57 Hussain AR, Ahmed SO, Ahmed M, Khan OS, Al AbdulMohsen S, Platanias LC et al. Cross-talk between NFkB and the PI3-kinase/AKT pathway can be targeted in primary effusion lymphoma (PEL) cell lines for efficient apoptosis. PLoS One 2012 7: e39945.

58 Sin SH, Roy D, Wang L, Staudt MR, Fakhari FD, Patel DD et al. Rapamycin is efficacious against primary effusion lymphoma (PEL) cell lines in vivo by inhibiting autocrine signaling. Blood 2007; 109: 2165-2173.

59 Lee RK, Cai JP, Deyev V, Gill PS, Cabral L, Wood C et al. Herpesvirus-associated lymphomas azidothymidine and interferon-a induce apoptosis in herpesvirusassociated lymphomas. Cancer Res 1999; 59: 5514-5520. 
60 An J, Sun Y, Fisher M, Rettig MB. Antitumor effects of Bortezomib (PS-341) on primary effusion lymphomas. Leukemia 2004; 18: 1699-1704.

61 Abou-Merhi R, Khoriaty R, Arnoult D, El Hajj H, Dbouk H, Munier S et al. PS-341 or a combination of arsenic trioxide and interferon- $\alpha$ inhibit growth and induce caspase-dependent apoptosis in KSHV/HHV-8-infected primary effusion lymphoma cells. Leukemia 2007; 21: 1792-1801.

62 Saji C, Higashi C, Niinaka Y, Yamada K, Noquchi K, Fujimuro M. Proteasome inhibitors induce apoptosis and reduce viral replication in primary effusion lymphoma cells. Biochem Biophys Res Commun 2011; 415: 573-578.

63 Bhatt S, Ashlock B, Toomey NL, Diaz LA, Mesri EA, Lossos IS et al. Efficacious proteasome/HDAC inhibitor combination therapy for primary effusion lymphoma. J Clin Invest 2013; 123: 2616-2628.

64 Boulanger E, Meignin V, Oksenhendler E. Bortezomib (PS-341) in patients with human herpesvirus 8-associated primary effusion lymphoma. Br J Haematol 2008; 141: 557-563.

65 Uddin S, Hussain AR, Al-Hussein KA, Manoqaran PS, Wickrema A, Gutierrez Ml et al. Inhibition of phosphatidylinositol 3-kinase/AKT signaling promotes apoptosis of primary effusion lymphoma cells. Clin Cancer Res 2005; 11: 3102-3108.

66 Aoki Y, Feldman GM, Tosato G. Inhibition of STAT3 signaling induces apoptosis and decreases survivin expression in primary effusion lymphoma. Blood 2003; 101: 1535-1542.

67 Gasperini $P$, Tosato $G$. Targeting the mammalian target of Rapamycin to inhibit VEGF and cytokines for the treatment of primary effusion lymphoma. Leukemia 2009; 23: 1867-1874.
68 Bhatt S, Ashlock B, Natkunam Y, Ramos JC, Mesri E, Lossos I. Preclinical activity of brentuximab vedotin (SGN-35) in primary effusion lymphoma. Blood (ASH Annual Meeting) 2011; 118: S625 (Abstract 3728)

69 El Hajj H, Ali J, Ghantous A, Hodroj D, Daher A, Zibara K et al. Combination of arsenic and interferon- $\alpha$ inhibits expression of KSHV latent transcripts and synergistically improves survival of mice with primary effusion lymphomas. PLoS One 2013; 8: e79474.

70 Fujimuro $M$, Inoue $H$, Teishikata $Y$, Ishida $Y$, Yokosawa $H$. Apoptotic effect of ganciclovir on primary effusion lymphoma cells infected with Kaposi's sarcoma-associated herpesvirus. Nucleosides Nucleotides Nucleic Acids 2006; 25: 635-645.

71 Goto H, Matsuda K, Srikoon P, Kariya R, Hattori S, Taura M et al. Potent antitumor activity of zoledronic acid-induced $\mathrm{V} \gamma \mathrm{V} \delta 2 \mathrm{~T}$ cells against primary effusion lymphoma. Cancer Lett 2013; 331: 174-182.

72 Paul AG, Sharma-Walia N, Chandran B. Targeting KSHV/HHV-8 latency with COX-2 selective inhibitor nimesulide: a potential chemotherapeutic modality for primary effusion lymphoma. PLoS One 2011; 6: e24379.

73 Lan K, Murakami M, Bajaj B, Kaul R, He Z, Gan R et al. Inhibition of KSHV infected primary effusion lymphomas in NOD/SCID mice by $\gamma$-secretase inhibitor. Cancer Biol Ther 2009; 8: 2134-2141.

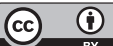

This work is licensed under a Creative Commons Attribution 3.0 Unported License. To view a copy of this license, visit http:// creativecommons.org/licenses/by/3.0/ 